\title{
Dylematy wynagrodzenia za pracę w polskich realiach gospodarki rynkowej
}

\section{Wprowadzenie}

Relacje pomiędzy rodzajem, ilością jakością świadczonej pracy a jej szeroko rozumianym wynagradzaniem stanowią kluczową kwestię ekonomiczna, społeczną i prawną. Zyskuje ona na znaczeniu wobec obserwowanych zjawisk na polskim rynku pracy oraz dzięki narastaniu i utrwalaniu się praktyk stosowania niepracowniczych form prawnych angażowania pracy, pozwalających na wyzysk. Praktyki te rodzą wiele zagrożeń znacząco obniżających standardy ochronne i społeczne pracy ${ }^{1}$.

Na tle obserwowanych tendencji w zakresie wynagradzania pracy powstaje pytanie, $w$ jakim stopniu regulacje prawne chronią słuszne interesy osób świadczących pracę? Czy funkcjonujące rozwiązania ekonomiczne uwzględniają wymiar społeczny pracy? Co jest przyczyną narastania zjawiska dominacji „,kapitału nad pracą" - wbrew racjom aksjologicznym. Co powoduje stopniowe osłabianie się funkcji ochronnych w stosunkach prawnych zatrudnienia? Powstaje także kwestia społecznych konsekwencji obserwowanej praktyki w dłuższym horyzoncie czasowym. Rozstrzygające $\mathrm{w}$ tym zakresie są relacje, jakie zachodzą pomiędzy państwem, pracodawcami i ich związkami a pracownikami i ich związkami. W opracowaniu zamierzam wskazać na niektóre węzłowe problemy, jakie zachodzą w stosunkach prawnych wynagradzania pracy².

* Dr hab. prof. nadzw., kierownik Katedry Prawa (1994-2012) Uniwersytetu Ekonomicznego w Katowicach.

${ }^{1}$ Szerzej: J. Wojtyła, Dylematy ochronnej funkcji prawa pracy w stosunkach prawnych zatrudnienia, [w:] Wolność i sprawiedliwość w zatrudnieniu. Księga pamiątkowa poświęcona Prezydentowi Rzeczypospolitej Polskiej Profesorowi Lechowi Kaczyńskiemu, Wyd. Uniwersytetu Gdańskiego, Gdańsk 2012, s. 383 i nast.

2 Zob. J. Wratny, Dylematy polityki prawa w zakresie wynagrodzenia za prace, [w:] Prawo pracy a wyzwania XXI wieku. Księga jubileuszowa Profesora Tadeusza Zielińskiego, Warszawa 2002. 


\section{O pojmowaniu wynagrodzenia za pracę $w$ kategoriach ekonomicznych, społecznych i prawnych}

Problematyka dochodów z pracy, w tym wynagrodzenia za pracę, ma wiele wymiaró $w^{3}$. Największe zainteresowanie występuje $w$ doktrynie ekonomicznej, głównie z zakresu nauk o pracy. Zwraca się szczególnie uwagę na motywacyjną (bodźcową) i kosztową funkcję płac. W naukach o polityce społecznej akcentuje się konieczność zachowania odpowiedniego poziomu dochodu z pracy jako warunku egzystencji zatrudnionego i jego rodziny, a także warunkującego jego rozwój osobowy, w tym zawodowy. Relacje, jakie zachodzą pomiędzy pracą i kapitałem są centralną kwestią doktryny katolickiej nauki społecznej Kościoła. Praca i związane z nią wynagrodzenie to klucz do wielu kwestii społecznych ${ }^{4}$. Współczesna doktryna polskiego prawa pracy, po zmianach ustrojowych, nie poświęca należytej uwagi problematyce szeroko rozumianego prawa wynagrodzenia za pracę. Wcześniej znaczący wkład wnosiły monografie M. Święcickiego i M. Seweryńskiego ${ }^{5}$, które pomimo zmian systemowych zachowują swoją aktualność. Przy istniejącym obecnie „,rozchwianiu” terminologicznym i niejednolitym pojmowaniu składników wynagrodzenia, trzeba wrócić do precyzyjnej charakterystyki poszczególnych elementów świadczeń ze stosunku pracy i ich charakteru prawnego ${ }^{6}$. Wobec konsekwencji urynkowienia wynagradzania pracy szczególnie ważna jest dzisiaj refleksja nad kwestiami kształtowania się i ochrony praw i interesów osób świadczących pracę w warunkach liberalizacji gospodarowania zasobami pracy ${ }^{7}$. Poznanie zjawisk związanych z kształtowaniem się dochodów z pracy wymaga ujęcia interdyscyplinarnego uwzględniającego różne wymiary łączące się $\mathrm{z}$ realizowaniem zasady wzajemności w różnych formach angażowania pracy w celach zarobkowych.

Doktryna prawa pracy odnosi się przede wszystkim do zagadnień wynagrodzenia za pracę w stosunku pracy. Rzadziej podnoszone są kwestie wynagrodzeń $\mathrm{w}$ niepracowniczych stosunkach pracy o charakterze administracyjno-prawnym ${ }^{8}$. Wyłania się wiele problemów związanych

${ }^{3}$ Ostatnio zwraca na to uwagę M. Seweryński, Uwagi o regulacji prawnej wynagrodzenia za prace, [w:] Praca i płaca, państwo i rynek, red. J. Hrynkiewicz, Warszawa 2014.

${ }_{4}$ Zob Jan Paweł II, Encyklika Laborem Exercens, [w:] Jan Paweł II, Dzieła zebrane, t. I, Encykliki, Kraków 2006.

${ }^{5}$ M. Święcicki, Prawo wynagrodzenia za prace, PWN, Warszawa 1963; M. Seweryński, Wynagrodzenie za prace, pojęcie, regulacja i ustalenie, PWN, Warszawa 1981.

${ }^{6}$ Ibidem, s. 35 i nast.

7 Zob. Wynagrodzenie za prace w warunkach społecznej gospodarki rynkowej, red. W. Sanetra, Warszawa 2009.

${ }^{8}$ Por. T. Zieliński, Stosunek prawa pracy do prawa administracyjnego, Warszawa 1977. 
z wynagradzaniem osób świadczących pracę w nietypowych stosunkach pracy, a w szczególności pomiędzy agencją a pracodawcą - użytkownikiem i wiążącą się z tym umową o pracę tymczasowa, umowy dotyczącej pracy wykonywanej $\mathrm{w}$ formie telepracy, umowy o staż zawodowy, umowy o zarządzanie zakładem pracy, umowy z osobą świadczącą pracę $\mathrm{w}$ gospodarstwie domowym (pracownicy domowi, pracownicy rodzinni świadczący pracę w przedsiębiorstwach rodzinnych), wykonujących pracę w ramach umowy o pracę nakładczą czy spółdzielcze umowy o pracę 9 .

Refleksji wymaga kwestia wynagradzania osób świadczących pracę na podstawie innej niż umowa o pracę (zatrudnienie niepracownicze) wykonywaną osobiście na rzecz jednego podmiotu zatrudniającego, świadczoną w sposób ciągły lub powtarzający się, za wynagrodzeniem przekraczającym połowę wynagrodzenia minimalnego ${ }^{10}$.

W warunkach gospodarki rynkowej koszt pracy stanowi dominującą pozycję w kosztach działalności podmiotów gospodarczych ${ }^{11}$. Szacuje się, że wynagrodzenia netto za pracę stanowią około 50\% kosztów ponoszonych przez pracodawcę $\mathrm{w}$ związku $\mathrm{z}$ zatrudnieniem pracownika. Proporcjonalnie do wzrostu wynagrodzenia odpowiednio wyższe są daniny publiczne ponoszone przez pracownika i pracodawcę. To w naturalny sposób tworzy silną barierę kosztową dla podnoszenia wynagrodzenia za pracę $\mathrm{w}$ stosunku pracy.

Trzeba tutaj zwrócić uwagę, że koszt ten nie obejmuje ryzyka osobowego ponoszonego przez pracodawcę ${ }^{12}$. Do kosztów pracy należy wliczyć także świadczenia socjalne i nakłady ponoszone przez pracodawcę na podnoszenie kwalifikacji pracownika oraz te, które są związane z doskonaleniem jego warsztatu pracy ${ }^{13}$. W piśmiennictwie wskazuje się na dalsze rodzaje obciążeń pracodawców ${ }^{14}$. Te pozawynagrodzeniowe elementy dodatkowo podnoszą sumę kosztów pracodawcy związanych z pracą.

${ }^{9}$ Propozycje uregulowania nietypowych stosunków pracy zostały przygotowane przez Komisję Kodyfikacyjną Prawa Pracy, powołaną na mocy Rozporządzenia Rady Ministrów z dn. 20 sierpnia 2002 r. DzU, 2002, poz. 1167. Komisja pracowała pod kierunkiem prof. Tadeusza Zielińskiego, a po jego śmierci prof. Michała Seweryńskiego. Zob. Kodeks pracy, Zbiorowy kodeks pracy - projekty, Wyd. Uniwersytetu Ekonomicznego w Katowicach, Katowice 2010.

10 Zob. art. 462 projektu Kodeksu pracy. Ibidem, s. 133.

11 Por. S. Borkowska, Strategie wynagrodzeń, Oficyna Ekonomiczna, Kraków 2001, s. 93.

12 Problem ten wyczerpująco ujmuje Ł. Pisarczyk, Ryzyko pracodawcy, Warszawa 2008, s. 143 i nast.

${ }^{13}$ Problem ten sygnalizowałem wcześniej. Zob. J. Wojtyła, Koszt pracy jako bariera rozwoju małych i średnich przedsiębiorstw, [w:] Podstawowe problemy rachunkowości jako dyscypliny naukowej i działalności praktycznej, red. J. Wojtyła, Katowice 2000, s. 239.

${ }^{14}$ S. Wanat, Przestrzenno-czasowa analiza kosztów pracy w Polsce i krajach Unii Europejskiej, [w:] Przestrzenno-czasowa analiza rynku pracy w Polsce i krajach Unii Europejskiej, red. A. Malina, Wyd. Uniwersytetu Ekonomicznego w Krakowie, Kraków 2008, s. 120 i nast. 
Pracodawcy dla łagodzenia obciążeń wynagrodzenia wspomnianymi daninami publicznymi, w zamian za niepodwyższanie wynagrodzenia, przyznawali pracownikom świadczenia pozawynagrodzeniowe. Miały one różną podstawę prawna, najczęściej wynikającą z regulaminów przyznawania innych świadczeń u danego pracodawcy, układów zbiorowych pracy czy też zawartych porozumień. Praktyka ta była stopniowo ograniczana poprzez przepisy prawa podatkowego, które regulowały kwestie możliwości zaliczania omawianych świadczeń do kosztów uzyskania przychodu. Analiza i badania praktyki wynagradzania pracowników, szczególnie mikro, małych i średnich przedsiębiorców, pozwalały zauważyć istnienie swoistej szarej strefy. Polegała ona na ustalaniu wynagrodzeń na niskim poziomie najniższego wynagrodzenia i dodatkowego kompensowania pracy poprzez nieewidencjonowane i nieopodatkowane świadczenia pieniężne. Czyniono tak, aby unikać kosztów związanych z daninami publicznymi. Takie praktyki zaciemniają rzeczywistość płacową.

$\mathrm{W}$ polityce prawa $\mathrm{w}$ tej dziedzinie zwraca uwagę narastający fiskalizm. Jaskrawym przykładem jest opodatkowanie ryczałtowych świadczeń kompensujących wydatki związane z korzystaniem przez pracownika $z$ własnego samochodu w celach służbowych. Takie świadczenie jest traktowane jako składnik wynagrodzenia za pracę. Innym przykładem mogą być okazjonalne, nawet drobne, opodatkowane świadczenia socjalne, traktowane jako element wynagrodzenia. Zaskakuje brak jednolitości $\mathrm{w}$ rozumieniu poszczególnych elementów wynagrodzenia $\mathrm{w}$ prawie pracy i prawie danin publicznych związanych z pracą.

Zróżnicowanie podstaw i form świadczeń na rzecz osób wykonujących pracę skłaniają do szerszego ujęcia uprawnień związanych z wynagradzaniem pracy. Wobec daleko idącego zróżnicowania form i praktyk wynagradzania pracy wydaje się bardziej adekwatne stosowanie pojęcia dochody z pracy, pozwalającego na ujęcie bardziej całościowe. Jego dominującym, ale nie wyłącznym, elementem w przypadku stosunku pracy będzie wynagrodzenie za pracę w jego kodeksowym rozumieniu. Idąc dalej można wyodrębnić świadczenia o charakterze zarówno materialnym, jak i niematerialnym, składające się łącznie na sumę korzyści wynikających z zatrudnienia ${ }^{15}$. Przykładem mogą być walory edukacyjne pracy, mogące stwarzać świadczącemu pracę możliwości rozwoju zawodowego. W warunkach tak szybkiego postępu zachodzącego w wielu dziedzinach, ten element może mieć równie istotne znaczenie dla pracownika, jak poziom wynagrodzenia za pracę. Możliwości dostępu poprzez pracę do wiedzy, jak i pozyskanie wartościowego doświadczenia zawodowego coraz bardziej zyskują na znaczeniu. Zauważalna staje się w wielu zawo-

${ }^{15}$ W sprawie pojęcia dochodu z pracy wypowiadał się wcześniej M. Święcicki, Prawo wynagrodzenia za pracę..., s. 10 i cytowana tam literatura. 
dach zależność pomiędzy wysokością płacy a spodziewanymi korzyściami rozwoju zawodowego. Niskie wynagrodzenie stażystów, praktykantów, aplikantów, nieadekwatne do ilości i jakości świadczonej pracy jest akceptowane przez zatrudnianych $\mathrm{w}$ związku $\mathrm{z}$ nadzieją na zaistnienie szansy na pozyskanie odpowiedniej pracy $\mathrm{w}$ następstwie legitymowania się doświadczeniem.

Refleksja nad społecznym wymiarem dochodu z pracy w obecnych realiach gospodarki rynkowej ustępuje miejsca poszukiwaniu w pracy ludzkiej przede wszystkim maksymalizacji zysku z pracy dla zatrudniającego. Przejawem jest tu tendencja do praktycznego eksponowania pracy jako towaru. Płacy nie mogą kształtować wyłącznie relacje rynkowe. Przykładem może służyć współczesna debata nad poziomem płacy minimalnej. Ma ona bardziej cechy swoistego targu dotyczącego jej wysokości pomiędzy partnerami społecznymi, którzy poszukują uzasadnienia dla swoich racji $w$ argumentach natury ekonomicznej, zapominając $w$ konsekwencji o jej wymiarze społecznym. Zapomina się o tym, że płaca powinna być nie tylko źródłem utrzymania dla pracownika i jego rodziny, ale zapewniać warunki do jego rozwoju zawodowego ${ }^{16}$. W tych rozważaniach warto poszukiwać uzasadnienia w całej aksjologii ludzkiej pracy. Sprawiedliwość naturalna winna być chroniona w warunkach gospodarki rynkowej ${ }^{17}$. Praca i związana z nią płaca są kluczem do kwestii społecznej i ekonomicznej współczesnej gospodarki ${ }^{18}$.

\section{Wpływ rynku pracy na kształtowanie się dochodów $\mathrm{z}$ pracy $\mathrm{w}$ stosunkach prawnych zatrudnienia}

Poziom bezrobocia jest papierkiem lakmusowym sprawności mechanizmów gospodarczych. Jest on od lat w Polsce na dramatycznie wysokim poziomie. Wzrosło ono według danych GUS z 8,8\% w roku 2008 do 13\% w 2013 r. Biorąc pod uwagę wahania sezonowe poziomu bezrobocia w Polsce w 2014 i 2015 r. utrzymuje się ono w granicach 12-12,5\%. Bardziej miarodajne są wskaźniki bezrobocia w poszczególnych regionach Polski. W województwie warmińsko-mazurskim np. bezrobocie wzrasta i w marcu 2015 r. sięgnęło 19,9\%. Do tego dochodzi bezrobocie nierejestrowane, występujące szczególnie w rolnictwie.

16 Jest to pogląd przyjmowany przez wielu autorów. Zob. C. Strzeszewski, Praca ludzka, Lublin 1978. Zajmuje centralne miejsce w nauce społecznej Kościoła. Zob. Sobór Watykański II, Konstytucja duszpasterska Gaudium et spes; Jan Paweł II, Encyklika Laborem...

17 Por. S. Borkowska, Wynagrodzenie godziwe - koncepcje i pomiar, Wyd. Instytut Pracy i Spraw Socjalnych, Warszawa 1999, s. 19 i nast.

18 Zob. Jan Paweł II, Encyklika Laborem... 
Zjawiskiem charakterystycznym jest narastający proces angażowania pracy $w$ innych formach prawnych niż na podstawie umowy o pracę. Szacuje się, że około $40 \%$ zatrudnionych świadczy pracę podporządkowaną poza stosunkiem pracy ${ }^{19}$. Brak jest w polskiej literaturze pogłębionych analiz dotyczących warunków umów, na jakich jest świadczona praca $\mathrm{w}$ zatrudnieniu atypowym czy niepracowniczym. Umowy określane jako "alternatywne" są charakterystyczne w typach gospodarki liberalnej, funkcjonującej m.in. w USA. Ich występowanie trzeba postrzegać przy uwzględnieniu rozwiązań systemowych i nie można ich analizować w sposób „wyrwany z kontekstu” 20 .

Informacje statystyczne dotyczące wysokości płac w Polsce odnoszą się do wynagrodzeń ze stosunku pracy i nie ujmują poziomu wynagradzania pracy poza nim. Pracownicy zatrudnieni na podstawie umowy o pracę pozostają pod ochroną przepisów prawa pracy, które - między innymi - ograniczają swobodę kontraktową pracodawcy ${ }^{21}$. Ochrony tej są pozbawione osoby które wykonują pracę na podstawie umów prawa cywilnego. W odróżnieniu od umów o pracę pozostawiają one stronom daleko idącą swobodę ustalania warunków, na jakich będzie świadczona praca $\mathrm{w}$ ramach umów: zlecenia, o dzieło, nienazwanych umów cywilnoprawnych itp. ${ }^{22}$ Obserwacja praktyki wskazuje na powszechnie bardzo niski poziom wynagradzania pracy $\mathrm{w}$ tych formach prawnych. Te wynagrodzenia pozostają poza regulacją określającą poziom płacy minimalnej. Szczególnie w warunkach wysokiej podaży pracy, swoboda kontraktowa na gruncie prawa cywilnego pozwala na jaskrawe wykorzystywanie przewagi ekonomicznej przez dającego pracę. Dążenie do maksymalizacji zysku poprzez obniżanie kosztów pracy motywuje do zatrudniania wykonawców w formach cywilnoprawnych, w których strony umowy mogą dowolnie ustalać wysokość wynagrodzenia w granicach swobody kształtowania treści umowy regulowanej art. 353 (1) Kodeksu cywilnego. Na gruncie tego przepisu otwiera się możliwość częściowego przerzucania ryzyka gospodarczego na wykonawcę, który w tych formach zatrudnienia nie korzysta z ochrony, jaką są objęci pracownicy w stosunku pracy. Istniejące warunki ekonomiczne i brak koniecznej ochrony prawnej pozwoliły na wykształcenie się umów, które określam jako „umowy

${ }^{19}$ Podobnie: J. Stelina, Buchalteryzacja pól polityki społecznej - głózwe problemy polityki społecznej w XXI wieku, [w:] Praca i płaca..., s. 49.

${ }^{20}$ Zob. P. Cappelli, J. Keller, A study of the extent and potential causes of alternative employment arrangements, „Industrial and Labor Relations Review” 2013, vol. 66, s. 874 i nast.

${ }^{21}$ Zob. L. Kaczyński, Zasada swobody umów w prawie pracy po nowelizacji kodeksu pracy, „Państwo i Prawo” 1977, z. 3.

${ }^{22}$ Zwracałem na to uwagę, zob. Dylematy ochronnej funkcji prawa pracy..., s. 390. 
wyzysku". Deprecjonują one etos pracy, godząc w uznane wartości, które powinny być chronione. W skrajnych przypadkach „umów wyzysku” można poszukiwać ochrony w klauzulach generalnych: zasad współżycia społecznego czy też - społeczno-gospodarczego przeznaczenia prawa, które wyznaczają granice wykonywania praw podmiotowych ${ }^{23}$. Nie są one wykorzystywane jako instrument ochrony przed omawianymi umowami godzącymi w zasady słuszności ${ }^{24}$. Głęboko niesprawiedliwy jest pogłębiający się podział na świadczących pracę $\mathrm{w}$ ramach stosunku pracy i tych, którzy wykonują pracę poza regulacjami kodeksu pracy ${ }^{25}$. Jest to szczególnie widoczne w sferze wynagradzania pracy.

\section{Uwarunkowania prawne wynagradzania pracy}

Obserwujemy narastające zróżnicowanie sytuacji prawnej i ekonomicznej osób świadczących pracę na rzecz podmiotu zatrudniającego w zależności od formy prawnej angażowania pracy. Rodzi się pytanie o granice dyferencjacji rzutującej bezpośrednio na nierówności w wynagradzaniu pracy i w konsekwencji na poziom egzystencji wykonującego pracę i jego rodziny. Czy pod ochroną prawa może pozostawać tylko praca wykonywana na podstawie stosunku pracy i stosunków pokrewnych $\mathrm{w}$ ramach regulacji kodeksu pracy?

W doktrynie katolickiej nauki społecznej rozpatruje się pracę $\mathrm{w}$ jej różnych formach i wymiarach. Zajmuje ona centralne miejsce $\mathrm{w}$ poszukiwaniu rozwiązań kwestii społecznej ${ }^{26}$. $Z$ równie szerokim ujęciem pracy spotykamy się w innych naukach o pracy, które łączą ludzką pracę z zatrudnieniem, a nie ograniczają jej tylko do jej świadczenia w stosunku pracy. Postanowienia Konstytucji odnoszą się do wszelkiej pracy wykonywanej $\mathrm{w}$ różnych formach zatrudnienia ${ }^{27}$. Zgodnie $\mathrm{z}$ art. 24 Konstytucji RP „praca znajduje się pod ochroną Rzeczypospolitej Polskiej. Państwo sprawuje nadzór nad warunkami wykonywania pracy". Proklamowana w art 20 Konstytucji zasada społecznej gospodarki rynkowej wyznacza, miedzy innymi, kierunki polityki prawa w zakresie regulowania ustroju pracy.

${ }^{23}$ Szerzej: M. Zieliński, Klauzule generalne w prawie prywatnym, [w:] System prawa prywatnego. Prawo cywilne. Część ogólna, t. I, red Z. Radwański, Warszawa 2007, s. 331 i nast.

${ }^{24} \mathrm{Na}$ gruncie obserwowanej praktyki jest to problem wymagający szerszej refleksji. Zob. także T. Zieliński, Klauzule generalne w prawie pracy, Warszawa 1988.

25 J. Wojtyła, Dylematy ochronnej funkcji prawa pracy...

${ }^{26}$ Jan Paweł II, Encyklika Laborem... i wskazane tam kwestie zagrożeń dla „porządku pracy ludzkiej".

${ }^{27}$ Tak uzasadnienie do Kodeksu Pracy, Kodeks pracy, Zbiorowy kodeks pracy, projekty..., S. 150. 
Bezpieczeństwo pracy i inne prawa obywatelskie mają służyć każdemu (art. 66 Konstytucji). Zasada demokratycznego państwa prawnego urzeczywistniająca zasady sprawiedliwości społecznej, wskazana w art. 2 Konstytucji, jest szczególnym zobowiązaniem państwa odnoszącym się także do stosunków prawnych zatrudnienia - w tym wynagradzania pracy. Wymaga to zapewnienia ochrony zatrudnienia osobom świadczącym pracę na rzecz podmiotu zatrudniającego poza stosunkiem pracy. Obecna polityka prawa $w$ omawianych stosunkach prawnych zatrudnienia pozostaje w kolizji z zasadami sprawiedliwości społecznej. Brak ochrony powoduje wkomponowanie umów wyzysku w mechanizm degradacji pracy i osiąganie nieuprawnionych społecznie zysków przez podmioty zatrudniające.

W łagodzeniu zjawisk bezrobocia podnoszony jest argument, że lepsza jakakolwiek praca niż żadna praca. Nie wymaga dowodu szkodliwość takiej tezy z punktu widzenia wartości pracy i jej wynagradzania ${ }^{28}$. Sprzyja to procesom jej dehumanizacji ${ }^{29}$. Formalnie takie zatrudnienie poprawia wskaźniki bezrobocia. Zaciemnia jednak obraz rynku pracy, ponieważ osoby skazane na niskie zarobki, poniżej minimum socjalnego, nie mają szans na rozwój zawodowy i w konsekwencji pozostają nadal w kręgu ubóstwa ${ }^{30}$.

Odpowiednia polityka społeczno-gospodarcza i odpowiadająca jej polityka prawa pracy powinny się koncentrować na szeroko rozumianej promocji pracy. W moim przekonaniu, pozostaje ona nadrzędna $\mathrm{W}$ stosunku do polityki zatrudnienia. Powinien temu odpowiadać odpowiedni „porządek aksjonormatywny".

Nie jakakolwiek praca, ale praca godna i godziwie wynagradzana, sprzyjająca rozwojowi osobowości człowieka jest kluczem do postępu społecznego i gospodarczego. Brak jest racji ekonomicznych dla promowania Polski jako kraju o dobrze wykształconej, taniej sile roboczej. Przykłady krajów „starej” Unii Europejskiej o wielokrotnie wyższej płacy podstawowej, jak i średniej dowodzą istnienia korelacji pomiędzy postępem gospodarczym a wynagrodzeniem. W tym ujęciu centralne miejsce zajmuje jakość stanowiska pracy czy rodzaju proponowanej pracy.

Wynagrodzenie pracy w oczywisty sposób wpływa na jakość pracy rozpatrywanej $\mathrm{w}$ kontekście satysfakcji materialnej pozwalającej na zaspokojenie potrzeb świadczącego pracę i jego rodziny ${ }^{31}$. Dlatego koniecz-

${ }^{28}$ Szereg problemów polityki prawa w zakresie wynagrodzenia za pracę podnosi J. Wratny, Dylematy polityki prawa w zakresie wynagrodzenia za prace..., s. 531 i nast.

${ }^{29}$ Zwraca na to uwage J. Bieńkowska, Problemy kształtowania pracy w warunkach niepewności, „Humanizacja Pracy” 2014, nr 1, s. 81 i nast.

${ }^{30}$ Tak J. Wojtyła, Państwo prawa czy rachunku ekonomicznego..., s. 41, podobnie J. Stelina, Praca i ptaca państwo i rynek..., s. 203.

${ }^{31}$ Zob. W. Golnau, Znaczenie płacy minimalnej dla funkcjonowania rynku pracy, Wyd. Uniwersytetu Gdańskiego, Gdańsk 2007. 
ne jest uwzględnianie nie tylko elementów ekonomicznych, ale także społecznych zatrudnienia ${ }^{32}$. Pozwoli to na pełniejszą ocenę warunków, na jakich jest świadczona praca i tego, czy wynagrodzenie spełnia konstytucyjne kryteria sprawiedliwości społecznej. Dla zapewnienia godziwego (sprawiedliwego) wynagrodzenia pracy trzeba się odwoływać do Europejskiej Karty Społecznej ${ }^{33}$ oraz ustaleń Komitetu Niezależnych Ekspertów, a także art. 2 i art. 3 Konwencji nr 131 Międzynarodowej Organizacji Pracy, dotyczącej kryteriów ustalania płac minimalnych. Są to ważne punkty odniesienia dla oceny poziomu wynagradzania wykonawców pracy w różnych formach prawnych jej świadczenia.

Analiza poziomu wynagrodzeń pracowniczych w stosunku pracy wskazuje na zjawisko ich spłaszczania na niskim poziomie. Powszechnie stosowana metoda liczenia średniej czy minimalnej płacy jako średniej arytmetycznej nie oddaje obrazu tego zjawiska. Pomija poziom wynagrodzeń w stosunkach niepracowniczych i nie wskazuje na rozkład poziomu wynagrodzeń. Tutaj miarodajna dla naszych rozważań byłaby średnia ujmowana jako dominanta. Poziom wynagrodzenia jest ujmowany jako płaca brutto. Zaciemnia to obraz poziomu płacy, nie informuje bowiem o wysokości danin publicznych. Dlatego bardziej miarodajna jest informacja o płacy netto. W kontekście oceny poziomu dochodu pracownika rzeczywisty obraz daje płaca realna. Ta jednak wymaga uwzględniania wysokich obciążeń podatkowych związanych z nabyciem produktów lub usług (m.in. podatek vat, cit). Stale narastający poziom danin publicznych umniejsza realny poziom wynagrodzenia. Brak jest precyzyjnych analiz poziomu realnych dochodów osób świadczących pracę w warunkach odpowiadających zatrudnieniu pracowniczemu w różnych niepracowniczych czy atypowych formach zatrudnienia. Zagrożenia są tutaj poważne, biorąc pod uwagę brak lub bardzo ograniczony zakres ochrony wynagrodzenia $\mathrm{w}$ tej grupie zatrudnionych.

Artykuł 78 Kodeksu pracy definiuje zasady ustalania wysokości wynagrodzenia za pracę. W treści wskazanej regulacji eksponowane są obiektywne kryteria zmierzające do urzeczywistnienia zasady sprawiedliwości w ustalaniu poziomu wynagradzania za pracę ${ }^{34}$. Niestety praktyka wynagradzania pozostaje pod wpływem relacji, jakie zachodzą pomiędzy podażą a popytem na konkretną pracę. Wprawdzie powołany przepis daje możliwość dochodzenia korekty wynagrodzenia, które rażąco narusza wskazane kryteria, jednak w praktyce nie ma ona znaczenia.

${ }^{32}$ Zob. M. Olędzki, Kształtowanie jakości pracy. Propozycja dialogu, Warszawa 1981, s. 26 oraz idem, Zatrudnienie społecznie racjonalne, Warszawa 1985; J. Wojtyła, Instrumenty polityki racjonalnego zatrudnienia..., s. 11 i nast.

${ }_{33}$ Zob. art. 4 i następne Europejskiej Karty Społecznej z 1996 r. (zrewidowanej).

${ }^{34}$ Zob. K. Raczka, Wynagrodzenie za prace, [w:] M. Gersdorf, K. Rączka, M. Raczkowski, Komentarz do Kodeksu pracy, Warszawa 2010, s. 491. 
Odrębną kwestią jest problem jedności czy dyferencjacji wysokości wynagrodzenia minimalnego. Należałoby promować model, w którym wynagrodzenie minimalne byłoby zróżnicowane $\mathrm{w}$ odniesieniu do poszczególnych grup zawodowych: w układach zbiorowych pracy, porozumieniach zbiorowych obejmujących dane grupy zawodowe. De lege lata jest to możliwe pod warunkiem "rewitalizacji" metody dialogu społecznego w kształtowaniu wynagrodzeńn ${ }^{35}$. Odpowiednie regulacje wynagrodzeń $w$ układach zbiorowych pracy lub porozumieniach moga obejmować także świadczących pracę na innej podstawie prawnej niż stosunek pracy. Nie jest to jednak wykorzystywane w praktyce.

Mimo zasady ,społecznej gospodarki rynkowej opartej na solidarności, dialogu i współpracy partnerów społecznych" jako podstawy ustroju zawartej w art. 20 Konstytucji RP zamiera dialog społeczny jako jedna z metod kształtowania stosunków zatrudnienia. Jedną z głównych tego przyczyn jest, w mojej opinii, dyktat pracodawców powodowany stale utrzymującym się wysokim poziomem bezrobocia .

Przyczyn szeregu patologicznych zjawisk w wynagradzaniu zatrudnionych upatruję w słabej ochronie wykonywanej przez Państwową Inspekcję Pracy, która nie wykorzystuje danych jej instrumentów. Zatrudnieni, w obawie przed dyskryminacją i utratą pracy, godzą się na praktyki wyzysku. Pogłębianiu się nieprawidłowości, m.in. w zakresie wynagrodzeń, sprzyja proces narastania drastycznych różnic w wysokości wynagrodzeń. $Z$ jednej strony niski ich poziom sprzyja wykształcaniu się licznej grupy „ubogich pracujących", podczas gdy wysokie wynagrodzenia kadry zarządzającej są warunkowane utrzymywaniem odpowiedniego poziomu wydajności pracy przy utrzymywaniu na niskim poziomie kosztów pracy. Jest to bardzo widoczne $\mathrm{w}$ praktyce małych i średnich przedsiębiorstw ${ }^{36}$. Obserwowana praktyka nie sprzyja kształtowaniu się sprawiedliwego ładu w zakresie wynagradzania zatrudnionych. Pogłębia to proces narastania prymatu kapitału nad praca, stanowiąc zagrożenie dla kształtowania się ładu w stosunkach pracy.

\section{Dylematy wynagradzania pracy w zatrudnieniu}

Wynagrodzenie za pracę stanowi najważniejszy element w kosztach pracy, jakie ponosi podmiot zatrudniający. Najprostszą drogą redukowania kosztów pracy jest redukowanie zatrudnienia, ucieczka od umów o pracę w kierunku zatrudnienia niepracowniczego lub korzystania z pra-

${ }^{35}$ Szerzej J. Wojtyła, Państwo prawa..., s. 43.

36 Szerzej J. Wojtyła, Prawo pracy z perspektywy rozwoju małych $i$ średnich przedsiębiorstw, [w:] Prawo pracy a wyzwania..., s. 388 i nast.; Państwo prawa..., s. 41. 
cy osób, które ją wykonują jako indywidualni przedsiębiorcy w formule samozatrudnienia. Takie działania powodują szereg wskazanych w tym opracowaniu nieprawidłowości. Na tle dokonanych obserwacji konieczna jest refleksja nad kierunkami koniecznych zmian ustroju pracy pozwalających na respektowanie konstytucyjnych i pozakonstytucyjnych zasad sprawiedliwości $\mathrm{w}$ wynagradzaniu za pracę. $\mathrm{W}$ tych poszukiwaniach warto powrócić do przypomnienia całej aksjologii pracy $\mathrm{w}$ ramach społecznej gospodarki rynkowej upatrując $w$ tym zapory dla traktowania pracy jako towaru, którego wartość wyznacza ",niewidzialna ręka rynku” i jej mechanizmy. Należy uznać, że wynagrodzenie jest podstawą bytu rodziny i jej promocji. Wynagrodzenie pracy jest także warunkiem utrzymania kompetencji zawodowych pracującego, którego w dużej mierze obciążają koszty kształcenia i doskonalenia zawodowego. W tym miejscu nasuwa się pytanie o faktyczną moc sprawczą regulacji prawnej chroniącej pracę i jej wynagradzanie.

Polityka prawa pracy powinna być otwarta na ochronę szeroko rozumianej pracy wykonywanej na rzecz podmiotu zatrudniającego. Przeprowadzone rozważania uzasadniają potrzebę prowadzenia polityka promocji i ochrony pracy, a nie tylko zatrudnienia w ramach stosunku pracy. Powinno to zapobiegać zjawiskom wyzysku pracy w innych formach świadczenia pracy niż stosunek pracy. W moim przekonaniu uzasadniona jest teza o konieczności odpowiednich zmian systemowych regulacji ustroju pracy. Wynagradzanie pracy odgrywa kluczową rolę $\mathrm{w}$ tym zakresie. Ważnym krokiem w tym kierunku są rozwiązania proponowane w projektach Kodeksu pracy i Zbiorowego kodeksu pracy przedstawione przez Rządową Komisję Prawa Pracy w połowie $2007 \mathrm{r} \cdot{ }^{37}$ Niezrozumiałe jest zablokowanie i nienadanie biegu legislacyjnego ukończonym projektom. $Z$ perspektywy czasu można ocenić, jak pozytywną rolę mogły odegrać zawarte w projektach propozycje regulacji m.in. atypowych i niepracowniczych stosunków pracy, dialogu społecznego w zakresie kształtowania uprawnień pracowniczych. Szansa na stworzenie mechanizmów pozwalających na łagodzenie konfliktu pomiędzy , pracą i kapitałem” została odroczona na rzecz prymatu kapitału nad praca, której sprzyja stale utrzymujące się wysokie bezrobocie. Partnerstwo i dialog powinny stać metodą kształtowania ładu w stosunkach prawnych zatrudnienia. Jest to droga do budowania modelu wspólnoty oraz solidarności i odchodzenie od modelu konfrontacyjnego. Warunkiem jest jednak „,rewitalizacja” wskazanej metody.

W badaniach, jak i w praktyce konieczne staje się podjęcie pogłębionej dyskusji nad relacjami, jakie zachodzą między państwem - pracobiorcami, pracownikami i ich przedstawicielstwami - w warunkach społecznej

${ }^{37}$ Zob.: Kodeks pracy, Zbiorowy Kodeks pracy... 
gospodarki rynkowej tak, aby rachunek ekonomiczny był łączony z rachunkiem społecznym. Dominacja kalkulacji ekonomicznej w procesach angażowania pracy powoduje groźne zjawisko prymatu nad ochronnymi regulacjami w stosunkach prawnych pracy i zatrudnienia.

\section{Bibliografia}

Bieńkowska J., Problemy kształtowania pracy w warunkach niepewności, „Humanizacja Pracy” 2014, nr 1.

Borkowska S., Strategie wynagrodzeń, Oficyna Ekonomiczna, Kraków 2001.

Cappelli P., Keller J., A study of the extent and potential causes of alternative employment arrangements, „Industrial and Labor Relations Review” 2013, vol. 66.

Golnau W., Znaczenie płacy minimalnej dla funkcjonowania rynku pracy, Wyd. Uniwersytetu Gdańskiego, Gdańsk 2007.

Jan Paweł II, Encyklika Laborem Exercens, [w:] Jan Paweł II, Dzieła zebrane, t. I, Encykliki, Kraków 2006.

Kaczyński L., Zasada swobody umów w prawie pracy po nowelizacji kodeksu pracy, „Państwo i Prawo" 1977.

Kodeks pracy, Zbiorowy kodeks pracy - projekty, Wyd. Uniwersytetu Ekonomicznego w Katowicach, Katowice 2010.

Olędzki M., Kształtowanie jakości pracy. Propozycja dialogu, Warszawa 1981.

Olędzki M., Zatrudnienie społecznie racjonalne, Warszawa 1985.

Pisarczyk Ł., Ryzyko pracodawcy, Warszawa 2008.

Rączka K., Wynagrodzenie za pracę, [w:] M. Gersdorf, K. Rączka, M. Raczkowski, Komentarz do Kodeksu pracy, Warszawa 2010.

Seweryński M., Uwagi o regulacji prawnej wynagrodzenia za pracę, [w:] Praca i płaca, państwo i rynek, red. J. Hrynkiewicz, Warszawa 2014.

Seweryński M., Wynagrodzenie za pracę, pojęcie, regulacja i ustalenie, Warszawa 1981.

Święcicki M., Prawo wynagrodzenia za prace, PWN, Warszawa 1963.

Wanat S., Przestrzenno-czasowa analiza kosztów pracy w Polsce i krajach Unii Europejskiej, [w:] Przestrzenno-czasowa analiza rynku pracy w Polsce i krajach Unii Europejskiej, red. A. Malina, Wyd. Uniwersytetu Ekonomicznego w Krakowie, Kraków 2008.

Wojtyła J., Dylematy ochronnej funkcji prawa pracy w stosunkach prawnych zatrudnienia, [w:] Wolność i sprawiedliwość w zatrudnieniu. Księga pamiatkowa poświęcona Prezydentowi Rzeczypospolitej Polskiej Profesorowi Lechowi Kaczyńskiemu, Wyd. Uniwersytetu Gdańskiego, Gdańsk 2012.

Wojtyła J., Koszt pracy jako bariera rozwoju małych i średnich przedsiębiorstw, [w:] Podstawowe problemy rachunkowości jako dyscypliny naukowej i działalności praktycznej, red. J. Wojtyła, Katowice 2000.

Wratny J., Dylematy polityki prawa w zakresie wynagrodzenia za prace, [w:] Prawo pracy a wyzwania XXI wieku. Księga jubileuszowa Profesora Tadeusza Zielińskiego, Warszawa 2002.

Zieliński M., Klauzule generalne w prawie prywatnym, [w:] System prawa prywatnego. Prawo cywilne. Część ogólna, t. I, red. Z. Radwański, Warszawa 2007.

Zieliński T., Klauzule generalne w prawie pracy, Warszawa 1988.

Zieliński T., Stosunek prawa pracy do prawa administracyjnego, Warszawa 1977. 


\title{
Dillemmas over Remuneration for Work in the Polish Realities of the Market Economy
}

\begin{abstract}
Summary
Observation of the business practise leads to the conclusion that non-standard forms of work is developing dynamically. The process of replacing employment forms protected with the provisions of the Labour Law with the civil law contracts is growing. Civil law contracts provide great flexibility in determining mutual commitments and - under high unemployment - enables the dictate of the employing entity which basic aim is to lower the labour costs. Therefore people are undertaking employment under adverse conditions which I describe as 'Exploitation Agreements'. The 'adverse conditions' are particularly clear in the diversification of the remuneration between the standard and non-standard forms of employment. The situation has been intensified with the unprecedented phenomenon of economic migration observed in the recent years.

The chapter signals main legislation dilemmas concerning remuneration mostly by formulating specific postulates de lege lata and de lege ferenda. It is being emphasised that wider labour protection policy is required including issues related to remuneration. This responsibility is derived from the articles of the Constitution which proclaim social market economy and also protection of widely understood labour which cannot be restricted to employment forms defined in the Labour Law Code. The author refers to the projects of the Labour Law and Collective Labour Law developed by the Governmental Codification Committee indicating possible positive role of the recommended systematic solutions. The chances to create mechanisms enabling alleviating conflicts between the labour and the capital have been postponed due to the primacy of the capital over the labour which is growing under high unemployment circumstances.
\end{abstract}

